Int. J. Electrochem. Sci., 12 (2017) $8368-8380$

\title{
An Electrochemical Investigation of the EDTA Influence on the Cobalt-Manganese Electrodeposition in Aqueous Chloride Electrolytes
}

\author{
Huihui Zhang ${ }^{1, *}$, Juntao Yuan ${ }^{2}$, Ming Zhu ${ }^{1}$ \\ ${ }^{1}$ School of Materials Science and Engineering, Xi'an University of Science and Technology, Xi'an \\ 710054, China \\ ${ }^{2}$ State Key Laboratory of Performance and Structural Safety for Petroleum Tubular Goods and \\ Equipment Materials, Tubular Goods Research Institute of CNPC, Xi'an 710077, China \\ *E-mail: hhzhang_xust@163.com
}

doi: $10.20964 / 2017.09 .51$

Received: 12 May 2017 / Accepted: 13 July 2017 / Published: 13 August 2017

\begin{abstract}
After subsequent proper heat treatment, a Co-Mn alloy coating is potentially a protective and conductive coating on ferritic stainless steel interconnects in solid oxide fuel cells. In this paper, we use electrochemical measurements to report the effects of EDTA (disodium ethylenediaminetetraacetate) in a chloride electrolyte on the Co-Mn electrodeposition process. The addition of EDTA to the chloride electrolyte significantly shifts the reduction reaction potential of cobalt in a more negative direction while slightly altering the discharging potential of manganese and most importantly, shortening to a great extent the discharge potential difference between $\mathrm{Co}^{2+}$ and $\mathrm{Mn}^{2+}$. Also, it is crucial to control the $\left[\mathrm{Co}^{2+}\right] /[$ EDTA] ratio to form completely complexed cobalt ions and a very small amount of complexed manganese ions, and thus to promote the deposition of the Co$\mathrm{Mn}$ alloy. The addition of EDTA to the chloride electrolyte is a promising way to prepare a Co-Mn alloy coating via electrodeposition.
\end{abstract}

Keywords: Electrodeposition; Interconnect; Cobalt-manganese; Disodium ethylenediaminetetraacetate; Cyclic voltammetry

\section{$\underline{\text { FULL TEXT }}$}

(C) 2017 The Authors. Published by ESG (www.electrochemsci.org). This article is an open access article distributed under the terms and conditions of the Creative Commons Attribution license (http://creativecommons.org/licenses/by/4.0/). 